\title{
Plant thionins: structure, biological functions and potential use in biotechnology
}

\author{
T.I. Odintsova $\otimes$, M.P. Slezina, E.A. Istomina
}

Vavilov Institute of General Genetics, RAS, Moscow, Russia

\begin{abstract}
Antimicrobial peptides (AMPs) are important components of defense system in both plants and animals. They represent an ancient mechanism of innate immunity providing rapid first line of defense against pathogens. Plant AMPs are classified into several families: thionins, defensins, nonspecific lipid-transfer proteins, hevein- and knottin-type peptides, hairpinins and macrocyclic peptides (cyclotides). The review focuses on the thionin family. Thionins comprise a plant-specific AMP family that consists of short ( $5 \mathrm{kDA})$ cysteine-rich peptides containing 6 or 8 cysteine residues with antimicrobial and toxic properties. Based on similarity in amino acid sequences and the arrangement of disulphide bonds, five structural classes of thionins are discriminated. The three-dimensional structures of a number of thionins were determined. The amphipathic thionin molecule resembles the Greek letter $\Gamma$, in which the long arm is formed by two antiparallel a-helices, while the short one, by two parallel $\beta$-strands. The residues responsible for the antimicrobial activity of thionins were identified. Thionins are synthesized as precursor proteins consisting of a signal peptide, the mature peptide region and the C-terminal prodomain. Thionins protect plants from pathogenic bacteria and fungi acting directly on the membranes of microorganisms at micromolar concentrations, although their precise mode of action remains unclear. In addition to plant pathogens, thionins inhibit growth of a number of human pathogens and opportunistic microorganisms, such as Candida spp., Saccharomyces cerevisiae, Fusarium solani, Staphylococcus aureus and Escherichia coli. Thionins are toxic to different types of cells including mammalian cancer cell lines. Transgenic plants expressing thionin genes display enhanced resistance to pathogens. A wide range of biological activities makes thionins promising candidates for practical application in agriculture and medicine.
\end{abstract}

Key words: antimicrobial peptides; thionins; plant immunity.

HOW TO CITE THIS ARTICLE:

Odintsova T.I., Slezina M.P., Istomina E.A. Plant thionins: structure, biological functions and potential use in biotechnology. Vavilovskii Zhurnal Genetiki i Selektsii =Vavilov Journal of Genetics and Breeding. 2018;22(6):667-675. DOI $10.18699 /$ VJ18.409

Received 21.03.2018

Accepted for publication 18.06 .2018

(c) AUTHORS, 2018

\section{Тионины растений: строение, биологические функции и перспективы использования в биотехнологии}

\author{
Т.И. ОАинцова 囚, М.П. Слезина, Е.А. Истомина
}

Институт общей генетики им. Н.И. Вавилова Российской академии наук, Москва, Россия

Антимикробные пептиды (АМП) - важнейшие компоненты защитной системы растений и животных, они представляют собой древний механизм врожденной устойчивости, обеспечивающий «первую линию обороны» против патогенов. Выделяют несколько семейств АМП растений: тионины, дефензины, неспецифические липид-переносящие белки (ЛПБ), гевеино- и ноттиноподобные пептиды, гарпинины, а также макроциклические пептиды (циклотиды). Обзор посвящен характеристике семейства тионинов. Тионины - характерное только для растений семейство АМП, состоящее из коротких ( 5 кДа) цистеинбогатых пептидов (с шестью или восемью остатками цистеина в молекуле), которые обладают антимикробными и токсическими свойствами. На основании сходства аминокислотных последовательностей и расположения дисульфидных связей выделяют пять структурных классов тионинов. Установлена пространственная структура ряда тионинов. Показано, что амфипатическая молекула тионина имеет форму греческой буквы Г, у которой длинное плечо образовано двумя антипараллельными а-спиралями, а короткое - двумя параллельными $\beta$-тяжами. Выявлены аминокислотные остатки, ответственные за антимикробную активность тионинов. Тионины синтезируются в виде предшественников, состоящих из сигнального пептида, зрелого пептида и С-концевого продомена. Тионины являются защитными пептидами растений против патогенных бактерий и грибов, которые действуют в микромолярных концентрациях непосредственно на мембраны микроорганизмов, хотя детальный механизм действия этих АМП до конца не выяснен. Помимо патогенов растений, тионины подавляют рост ряда патогенных и условно патогенных микроорганизмов человека, таких как Candida spp., Saccharomyces cerevisiae, Fusarium solani, Staphylococcus aureus, Escherichia coli. Тионины токсичны для различного типа клеток, включая линии раковых клеток млекопитающих. Трансгенные растения, в которых экспрессируются гены тионинов, обладают повышенной устойчивостью к патогенам. Широкий спектр антимикробной и токсической активности тионинов открывает возможности их практического использования в сельском хозяйстве и медицине.

Ключевые слова: антимикробные петиды; тионины; иммунитет растений. 
$\mathrm{D}$ uring their lifetime plants are constantly confronted with pathogens, and to combat them, they have developed various defense mechanisms. Synthesis of antimicrobial compounds of protein or non-protein nature provides an example. In the plant defense system, antimicrobial peptides (AMPs) are the most important protein constituents. AMPs represent an ancient innate immunity mechanism providing rapid and energy-saving first line of defense against pathogens. Plant AMPs share similar properties, such as small size of the molecules (less than $10 \mathrm{kDa}$ ), positive charge and amphiphilicity (Egorov, Odintsova, 2012; Tam et al., 2015; Sarethy, 2017). These structural peculiarities allow AMPs to interact either directly or via receptors with membranes of microorganisms and disturb their permeability that leads to inhibition of growth and development of pathogens. The vast majority of plant AMPs are cysteine-rich peptides; they contain an even number $(2,4,6,8$ or 10$)$ of cysteine residues that form disulfide bonds conferring high structural stability to AMPs molecules. Based on homology in amino acid sequences, cysteine motifs and three-dimensional structure, AMPs are classified into several families: thionins, defensins, non-specific lipid-transfer proteins, hevein- and knottin-type peptides, hairpinins, and macrocyclic peptides (cyclotides).

In recent years, AMPs have attracted a great deal of interest due to their promising practical applications in agriculture to control crop diseases and in medicine - to develop nextgeneration pharmaceuticals (de Souza Cândido et al., 2014; Guzmán-Rodríguez et al., 2015).

\section{Thionins}

\section{Structural characteristics}

Thionins are short ( $\sim 5 \mathrm{kDA})$ cysteine-rich peptides, which were first discovered in wheat endosperm (Balls et al., 1942). Later, they were found in many monocotyledonous and dicotyledonous plants. About 100 thionin sequences have been described in 15 plant species (Stec, 2006). In contrast to representatives of the defensin family found in both plants and animals, thionins are plant-specific. Thionins are classified into two main groups according to the number of cysteine residues: 6- or 8-Cys-containing peptides. Based on similarity in amino acid sequences and disulfide bond arrangement, thionins are divided into five structural classes (I-V).Class I thionins are found in seed endosperm of plants belonging to the Poaceae family. They consist of 45 amino acids, 8 of which are cysteines, and have high positive charge of the molecules. Class II thionins occur in leaves and nuts of the parasitic plant Pyrularia pubera and in leaves of barley (Hordeum vulgare). They are less basic compared to class I thionins and consist of 46-47 amino acid residues. They also have 8 cysteine residues in the molecule. Class III thionins were isolated from different mistletoe species, such as Viscum album, Phoradendron tomentosum, Phoradendron liga, and Dendrophthora clavata. They possess 45-46 amino acids and 3 disulfide bonds; the charge of their molecules is the same as in the class II thionins. From Crambe abyssinica seeds, thionins of class IV were extracted; they have 46 amino acids and 3 disulfide bonds and are neutral. A wheat thionin, which is a truncated variant of class I thionins, belongs to class V. Amino acid sequences of thionins belonging to different classes display high sequence similarity. Amino acid sequences of thionins from selected plant species are presented in Fig. 1.

All thionins are synthesized as $\sim 18 \mathrm{kDa}$ preproproteins, which consist of a signal peptide, a basic thionin domain and an acidic C-terminal propeptide. Within one species, the C-terminal propeptides are highly conserved; this especially refers to the position of 6 cysteine residues in the polypeptide chain (Schrader-Fischer, Apel, 1993). Homology in thionin acidic propeptides, although less pronounced, is also observed among acidic propeptides of different plant species. Conservation of the $\mathrm{C}$-terminal prodomain proves its vital functions for the precursor protein. Cleavage of the signal peptide and the $\mathrm{C}$-terminal propeptide occurs during post-translational processing of the precursor. The vacuolar proteinase was isolated from tobacco leaves, which cleaves the signal peptide from the precursor protein. The removal of the signal peptide is necessary for activation of thionin's toxic properties (Romero et al., 1997). From the etiolated barley seedlings, serine proteinase (subtilase) was isolated. This pyrolysin family enzyme performs processing of the thionin precursor by cleaving the C-terminal prodomain (Plattner et al., 2015). The role of the acidic C-terminal prodomain has not been clarified completely so far. It is supposed to serve for directional transport of the mature thionin to its final destination (vacuoles, cell walls, or protein bodies). Moreover, this prodomain neutralizes toxic properties of the mature thionin before it reaches the intercellular space or vacuole, thus protecting plant cells from their own toxin (Bohlmann, 1994). In addition, it may serve as an intramolecular chaperone providing thionin folding.

Upon pathogen attack, expression of thionin genes is regulated by methyl jasmonate; this plant hormone plays a key role in defense reactions. In Arabidopsis thaliana, differential regulation of thionin genes Thi2.1 and Thi2.2 was shown. Thi2.1 expression in flowers is induced by Fusarium oxysporum infection and regulated by methyl jasmonate, while Thi2.2 is expressed in seedlings, and its expression is jasmonate-independent (Stotz et al., 2013).

Three-dimensional structures of 6-Cys crambin from C. abyssinica seeds 8-Cys thionins from wheat and barley, and viscotoxin A3 from mistletoe leaves were resolved by X-ray crystallography. Some thionin structures were determined by NMR spectroscopy, namely those of phoratoxin A, crambin, viscotoxin $\mathrm{A} 3$ and $\mathrm{C} 1, \alpha$-hordothionin, purothionin, and hellethionin. In all cases, the amphipathic thionin molecule was shown resembles the Greek letter $\Gamma$, in which the long arm is formed by two antiparallel $\alpha$-helices, while the short one, by two parallel $\beta$-strands (Fig. 2). The groove between two structural domains appears to be of considerable importance for thionin functioning (Stec et al., 2004; Oard et al., 2007).

\section{Wheat purothionins}

In hexaploid wheat $T$. aestivum (AABBDD), three class I thionins, or purothionins, have been described. Purothionins- $\beta$, $-\alpha_{\mathrm{B}}$ and $-\alpha_{\mathrm{D}}$ are encoded by the genes pur $A 1$, pur B1, and pur D1 located on the long arms of chromosomes 1A, 1B, and 1D, respectively (Sánchez-Monge et al., 1979). Two $\beta$-purothionins have been described in T. monococcum and T. urartu, which are genome A donors to polyploid wheats. In addition, hexaploid wheat has class $\mathrm{V}$ thionins; their genes are 
Crambin

Phoratoxin A

Viscotoxin A2

Viscotoxin B

Viscotoxin $\mathrm{C} 1$

Hellethionin D

$\mathrm{Pp}-\mathrm{TH}$

$\alpha=$ hordothionin

$\beta$-hordothionin

$\alpha$-purothionin

$\beta$-purothionin

$\mathrm{TK}=\mathrm{AMP}=\mathrm{BP}$

TK-AMP-AP1

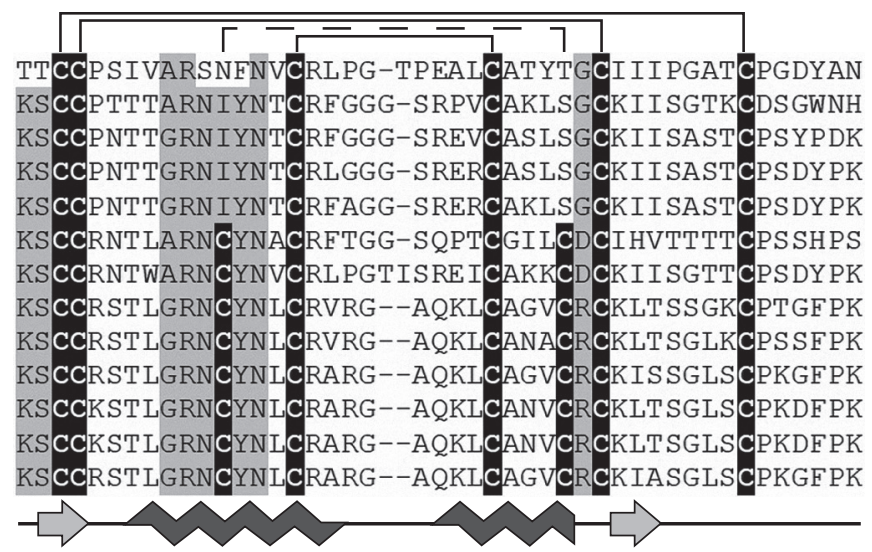

Fig. 1. Amino acid sequences of selected thionins: crambin from C. abyssinica (GenBank P01542.2); phoratoxin A from P. tomentosum (GenBank P01539.1); viscotoxin A2 (GenBank P32880.1), B (GenBank P08943.2), and C1 (GenBank P83554.1) from V. album; hellethionin D from Helleborus purpurascens (GenBank P60057.1); Pp-TH from P. pubera (GenBank P07504.1); a-hordothionin (GenBank AAA32966.1) and $\beta$-hordothionin (GenBank 1206255A) from H. vulgare; a-purothionin (GenBank CAA65313.1) and $\beta$-purothionin (GenBank CAA65312.1) from Triticum aestivum; TK-AMP-BP and TK-AMP-AP1 from Triticum kiharae (our unpublished data)

Cysteine residues are highlighted white on the black background. Functionally important residues are highlighted black on the grey background. The lines above sequences denote disulfide bonds. Thionin secondary structure elements are presented below: $\alpha$-helices and $\beta$-strands are shown in grey and lightgrey, respectively.

located several kilobases away from the genes of class I thionins on the long arms of chromosomes 1A, 1B, and 1D (Castagnaro et al., 1992). In hexaploid wheat species Triticum kiharae Dorof. et Migusch. to be a synthetic allopolyploid produced by crossing of Triticum timopheevii and Aegilops tauschii which is highly resistant to pathogens, we have also detected three thionins. Two of them, namely Tk-AMPAP1 and Tk-AMP-BP, were isolated from seeds and sequenced (our unpublished data). The Tk-AMP-BP structure has turned to be identical to $\beta$-purothionin from T. aestivum. T. kiharae transcriptome analysis by high throughput next-generation sequencing (NGS) technology has revealed much greater diversity of purothionins (our unpublished data). In order to search for thionin precursor transcripts, the algorithm based on conservative cysteine motifs characteristic to the C-terminal prodomain and the mature thionin domain was used (Silverstein et al., 2007). As a result, 15 transcripts encoding the precursors with characteristic cysteine motifs have been discovered in wheat seedlings (Fig. 3). All of them possessed thionin-specific and conserved 6-Cys-containing $\mathrm{C}$-terminal prodomain. In one transcript named c32154_g11, the cysteine-rich mature thionin region was deleted. This protein was $100 \%$ similar to the "uncharacterized protein LOG1097596362" from A. tauschii subsp. tauschii in NSBI database. In two other highly homologous precursors, the mature peptide regions had only 4 cysteine residues that is not typical for thionins. Those proteins are also annotated as "uncharacterized protein" from A. tauschii subsp. tauschii (99 and $100 \%$ similarity for c41117 g1 and c45947, respectively). The remaining precursors were very similar (64-100\%) to thionins or thionin-like proteins. In each of four precursors, there was a typical for thionins 8-Cys domain with two adjacent cysteine residues in the $\mathrm{N}$-terminal region of the molecule. In other precursors, three successive cysteine residues were found in the thionin domains, and the number of cysteine residues varied from seven to ten.

It is of interest that in lyme grass (Leymus arenarius L.), which is another cereal, by transcriptome analysis we have also detected 15 transcripts encoding the precursors with motifs typical for thionins, although only 4 of them were annotated as thionin-like proteins in NCBI database (Slavokhonova et al., 2015). In six hypothetical thionins, just as in typical thionins, there were six or eigt cysteine residues in the molecule including the two adjacent cysteine residues located in the

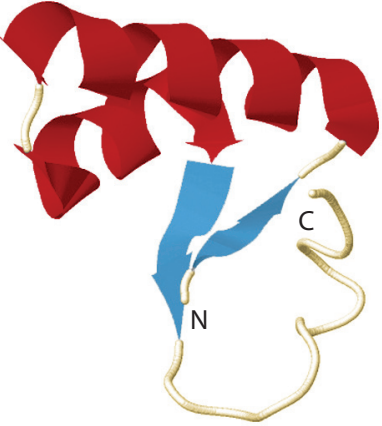

Hellethionin D

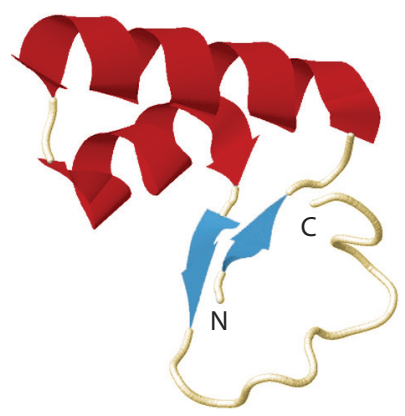

Viscotoxin C1

Fig. 2. Three-dimensional structure of thionins: hellethionin D (PDB: 1NBL) from $H$. purpurascens and viscotoxin C1 (PDB: 1ORL) from V. album.

a-helices and $\beta$-strands are shown in red and blue, respectively. $\mathrm{N}$ and $\mathrm{C}$ terminal regions of the thionin molecules are shown.

$\mathrm{N}$-terminal region. In other peptides, the number of cysteine residues varied from 5 to 14 . It is noteworthy that amino acid sequences of $L$. arenarius thionin-like proteins with three successive cysteine residues in the $\mathrm{N}$-terminal region of the molecule were similar to those of wheat.

Thus, transcriptome analysis has revealed new structural types of thionin-like proteins in wheat and related cereal species L. arenarius. Further research will focus on the analysis of antimicrobial activity of these new plant peptides.

\section{Structure-function relationship}

By now a number of thionins have been isolated and characterized, making it possible to establish the role of particular amino acid residues in the spatial structure and biological activity of the peptides. Studies on wheat purothionins have shown that modification of all amino groups significantly changes the charge of the molecule and results in loss of toxicity towards yeast cells and 
$\beta$-purothionin $\ldots|\ldots| \ldots|\ldots| \ldots|\ldots| \ldots|\ldots| \ldots|\ldots|$

*C43306 g14

${ }^{*} \mathrm{C} 43362-\mathrm{g} 21$

${ }^{*} \mathrm{C} 49559$ g25

${ }^{*} \mathrm{c} 43362$ g11

${ }^{*}{ }_{\mathrm{C} 49559}$ g22

${ }^{*} \mathrm{c} 44441-\mathrm{g} 12$

${ }^{*} \mathrm{C} 48818 \mathrm{~g} 11$

${ }^{*} \mathrm{C} 13320 \mathrm{~g} 11$

${ }^{*} \mathrm{c} 13366 \mathrm{~g} 11$

${ }^{*} \mathrm{c} 66152$-g11

$\star^{*} 79122-g 11$

${ }^{*} \mathrm{c} 6385 \mathrm{~g} 11$

C4111 $\overline{7} \mathrm{~g} 1$

c45947

c32154_g11

MGSKGLKGVMVCLIILGLVL---EQVQVEG----------KSCOKSTLGRNCYNLCRARGAOKL-CANVCRCKLTSGLSCEKDFPKLVL MVMMR GNNVKTLALILVVVGLVAIEQTQQVQ---------ASHCCCHLDSVPTYFDCRARSDS---TVSEC-CGSSDGYI-SDAAGFECIK MVMMR GNNVKTLALILVVVGLVAIEQTQQVQ---------ASHCCCHLDSVPTYFDCRAKSDS---TVSEC-CGVSAGYI-SDDAGFECK MVMMR GNNVKTLALILVVVGLVAIEQTQQVQ---------ASHCCCHLDSVPTYFDCRAKSDS---TVSEC-CGVSAGYI-SDDAGFECK MAMRGNNVKTLALMLVVVGLVALQQTQQVQ---------ASHCCCHLDSVPTYFKCREKSDS---TVSEC-CGVSAGYI-SDDAGFECK MVMMR GNNVKTLALMLVVVGLVALQQTQQVQ---------ASHCCODLKSVDTYFTCRQKSDS---TVSDC-CGASAGYI-SDAAGFECK MATNSRKSVIMGVVILVLVIQQAQVE---------AKSCCCSTSGRNCYNACRVTGASRKTCASLCGCKIID------KCVRPCD MEGKS GLRAVILILGAVIVIGSLVPLAQADPTAAATGADDAKFCOKDKIGS HCYAACITQYGP IPFCAFMCCCVQITSGRCPROCPTPAD MGSKGLKGVMVCLIILGLVLEQVQVE----------GKSCORTTLGRNCYNICRSRGA-KLCSTVCRCKLTSG----ISCPKGFP MGSKGLKGVMVCLIILGLVLEQVQVE---------GKSCCKSTLGRNCYNLCRARGAQ-KLCANVCRCKLTSG----LSCPKDFP ME SKHFIKSVIMCALILGLVPEQTQVAE---------GKSCCRDTRSRNCYNVCGERYPS -SSCSKMCGCVLTRD----RTCPREYP MGAGKNGAWS SMVMGVEILVVLIQ----------LECTIGWCDRACIIQ MVDAWWPLIAAAVPAIVAGQAIRVKRRRDEEQRLKAARGREK-SSDEVFVCERVCTSKR-----MLKKVGAFSKDPIPDTCVTVCG MVDAWWPLLAAAVPAIVAGQAIRVKRRRDEEQRLKAARGREK-SSDEVFVCERVCTSKR-------MLKKVGAFSKDPIPDTCVTVCG MAGQAPAVVAFALAAAIISTPPPQSENFSNIPPTIS

100

110

120

130

140

150

160

170

180

$\beta$-purothionin

${ }^{*} \mathrm{c} 43306 \mathrm{~g} 14$

${ }^{*} \mathrm{c} 43362$ g21

*c49559 g25

${ }^{*} \mathrm{C} 43362$ g11

${ }^{*} \mathrm{c} 49559$ g22

${ }^{*} \mathrm{C} 44441-\mathrm{g} 12$

${ }^{*} \mathrm{C} 48818 \mathrm{~g} 11$

* $\mathrm{c} 13320 \mathrm{~g} 11$

${ }^{*} \mathrm{c} 13366_{\mathrm{*}} \mathrm{g} 11$

* 66152 g11

$*^{*} 79122$ g11

${ }^{*} \mathrm{C} 6385 \mathrm{~g} 11$

$\mathrm{c} 4111 \overline{7} \mathrm{~g} 1$

c45947

c32154 g11

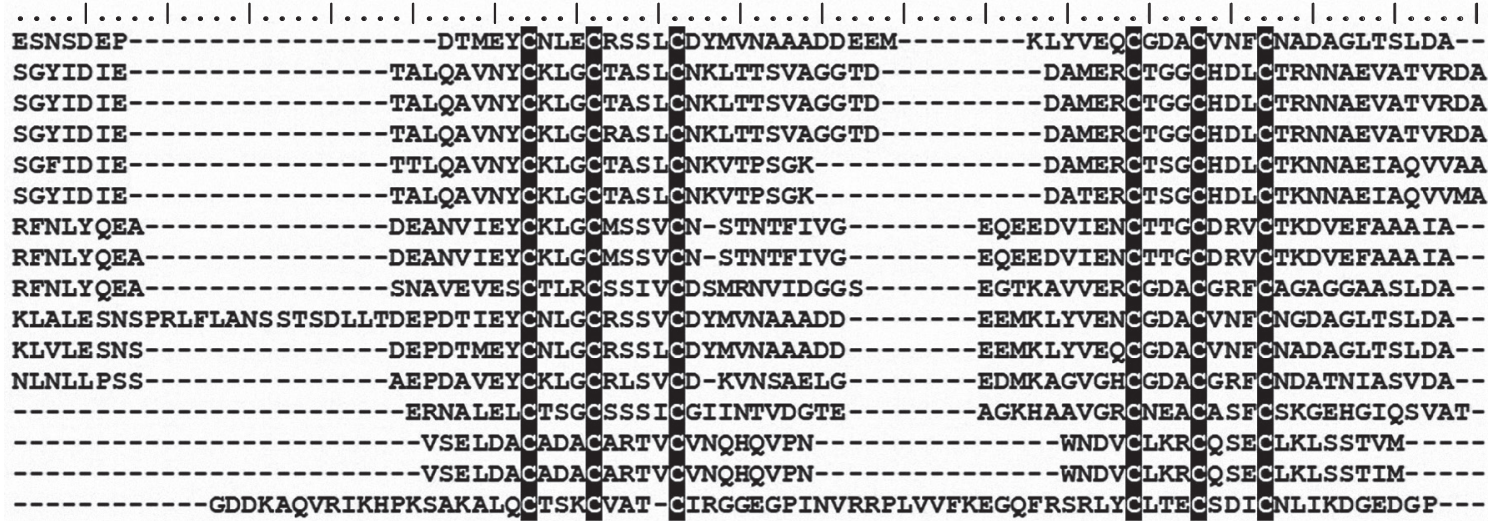

Fig. 3. Multiple alignment of translated sequences encoding T. kiharae thionin precursors. Polypeptides annotated as thionins or thionin-like proteins in NCBI database are marked with *.

${ }^{*}$ In $\beta$-purothionin precursor sequence (GenBank CAA65312.1), the mature peptide region is underlined. Cysteine residues are highlighted white on the black background.

mice. Modification of the only conservative tyrosine residue (Tyr-13) considerably diminishes toxicity as well. The data obtained demonstrate the importance of positively charged lysine groups for the interaction with the negatively charged surface of target cells and the role of a tyrosine residue at position 13 in toxic properties of the wheat thionin (Wada et al., 1982). Comparison of amino acid sequences of different thionins showed that not only cysteine residues, but some other amino acids, such as residues 1, 2, 9-14, and Tyr-13 that "cover" the groove between two structural domains of thionins are highly conserved as well, thus suggesting their importance for functioning of thionins. Based on the threedimensional structure of thionins, it was suggested that this conservative region binds to negatively charged phospholipids of cell membranes and replaces them from membranes, thus causing membrane solubilization and lysis (Stec et al., 2004). A nanopeptide corresponding to residues 7-15 in the thionin sequence was synthesized, in which Cys- 12 was replaced by serine. This peptide is supposed to be an active site of the thionin. This short peptide was shown to bind to the "receptor site" (to phosphatidylserine of the phospholipid membrane); however its binding capacity was not as strong as that of the native thionin (Osório e Castro, Vernon, 2003). Lys-1 and
Arg-10 make up a phosphate-binding site, while Ser-2 and Tyr-13 compose a glycerol-binding site. In turn, Asn-11 and Asn-14 stabilize homodimer formation due to intermolecular hydrogen bonds (Oard et al., 2007). L.P. Vernon and colleagues (1985) assume that position $8, \operatorname{Trp}-8$ in the thionin from Pyrularia is also essential for antimicrobial activity.

Comparison of toxic thionin sequences with that of non-toxic crabmin from $C$. abyssinica demonstrated that the conserved residues Lys-1 and Tyr-13 are crucial for toxicity, since in crabmin, Thr-1 and Phe-13 are located in corresponding positions. In addition, Arg-10 is considered to be important for the maintenance of the thionin spatial structure (Rao et al., 1993)

Using $P$. pubera $\mathrm{Pp}$-TH thionin containing four disulfide bonds as an example, it was shown that elimination of one disulfide bond significantly alters peptide folding (Vila-Perelló, Andreu, 2005). A truncated by $45 \%$ Pp-TH was synthesized; it comprised residues from $7^{\text {th }}$ to $32^{\text {nd }}$ of the native peptide, which form two antiparallel $\alpha$-helices stabilized by two disulfide bonds. The truncated peptide displayed the same antimicrobial activity towards a panel of microorganisms and the same mode of action as the intact Pp-TH (Vila-Perelló et al., 2005). In addition, in Pp-TH thionin from P. pubera, position 
32 is occupied by Asp-32 instead of Arg-32 characteristic of other 8-Cys thionins. To elucidate the role of this mutation, its analogue Pp-TH(D32R) was synthesized, in which the aspartic acid was replaced by arginine. In the modified peptide, the spatial structure was generally preserved, although some decrease in the content of $\alpha$-helices was noted. However, this synthetic peptide exhibited stronger inhibitory activity against some gram-negative bacteria, while its activity against other pathogens remained unchanged (Vila-Perelló et al., 2003). The $P$. pubera thionin was used as a template for designing shorter antimicrobial compounds but retaining the same antimicrobial activity as the native peptide (VilaPerelló et al., 2006).

\section{Biologic activity of thionins}

Thionins have long been known for their ability to inhibit growth of bacteria and fungi in vitro (Stuart, Harris, 1942). R. Fernandez de Caleya and his colleagues (1972) were the first to demonstate that thionins suppress growth of phytopathogenic bacteria, and they suggested the protective role of these proteins in planta. Further research showed that thionins inhibit growth of both gram-positive and gram-negative bacteria, phytopathogenic fungi and oomycetes with $\mathrm{IC}_{50}$ (concentration required for $50 \%$ inhibition of pathogen growth) usually from 1 up to $15 \mu \mathrm{g} / \mathrm{ml}$ (Stec, 2006). For wheat and barley thionins (class I thionins), the efficient concentration for $50 \%$ growth inhibition of Clavibacter michiganensis subsp. sepedonicus and Pseudomonas solanacearum was $2-3 \times 10^{-7}$ $\mathrm{M}$; for the pathogenic fungi, such as Rosellinia necatrix, Colletotrichum lagenarium, and Fusarium solani, it was $1-4 \times 10^{-6} \mathrm{M}$ (Molina et al., 1993). The wheat purothionin caused lysis of Rhizoctonia solani cells (rice pathogen, strain LR172), while visible changes in pathogen membranes were observed at the purothionin concentration of $0.5 \mu \mathrm{M}$ (Oard et al., 2004).

It is worth noting that thionins inhibit growth not only of plant pathogens, but those of humans and animals as well. For instance, the thionin-like peptides from Capsicum annuum were shown to suppress growth of yeasts Saccharomyces cerevisiae, Candida albicans, and Candida tropicalis, and bacteria Escherichia coli and Pseudomonas aeruginosa (Taveira et al., 2014, 2016). A thionin-like peptide (CaThi) from C. annuum inhibited growth of the fungus Fusarium solani by preventing formation of hyphae. An increase in membrane permeabilization, induction of $\mathrm{H}_{2} \mathrm{O}_{2}$ production, and activation of caspases were also recorded. The peptide was also shown to penetrate into the cells of the pathogen. In combination with fluconazole, synergism of the two antifungal agents was observed resulting in $100 \%$ death of $F$. solani cells (Taveria et al., 2017). The authors suppose that the pepper thionin causes apoptosis of fungal cells, however intracellular targets cannot be excluded either. In the endothelial cell line BE-E6E7, expression of Arabidopsis thionin Thi2.1 inhibited growth of E. coli, Staphylococcus aureus (including the isolate which causes mastitis in cows), and C. albicans (Loeza-Ángeles et al., 2008; Ochoa-Zarzosa et al., 2008a, b). Wheat thionins were shown to kill the cells of the parasitic protozoan Leishmania donovani causing visceral leishmaniasis (Berrocal-Lobo et al., 2009). Death of $L$. donovani cells results from a drastic increase in membrane permeability. The examples mentioned above open an opportunity for the use of thionins in treatment of human and animal diseases.

Apart from being destructive to microorganisms, thionins affect mammalian cell cultures (Carrasco et al., 1981; LoezaÁngeles et al., 2008), entire animals (mammals), (Coulson et al., 1942), and insect larvae (Kramer et al., 1979; Stec, 2006). During injection of wheat, barley or rye thionins into Manduca sexta larvae, the half lethal concentration was $17-46 \mu \mathrm{g} / \mathrm{g}$ (Kramer et al., 1979).

Thionins possess cytotoxic and anticancer activities on mammalian cells (Guzmán-Rodríguez et al., 2015). The thionin from $P$. pubera inhibits growth of mouse melanoma cells (B16) and cervical cancer cells (HeLa) with $\mathrm{IC}_{50}=50 \mu \mathrm{g} / \mathrm{ml}$. This thionin also exhibits cytotoxic activity causing hemolysis. The anticancer activity is due to membrane depolarization which causes activation of endogenous phospholipase $A_{2}$ resulting in modifications of membrane structure and cell death. Another group of thionins with anticance and cytotoxic activities includes viscotoxins. Viscotoxin B2 inhibits growth of rat sarcoma cells with $\mathrm{IC}_{50}=1.6 \mu \mathrm{g} / \mathrm{l}$ (Kong et al., 2004). Viscotoxins A1, A2 and A3 display cytotoxic activity on human lymphocytes, which is associated with induction of reactive oxygen species and membrane permeabilization. However, hemolytic properties of viscotoxins are less pronounced compared to other thionins (Coulon et al., 2002). Ligatoxin B from P. league is toxic to the cells of human lymphoma (U937GTB) and adenocarcinoma (ACHN) at a concentration of $100 \mu \mathrm{g} / \mathrm{ml}$. This thionin has a DNA-binding domain, and it was suggested that binding to DNA inhibits synthesis of nucleic acids (Li et al., 2002). All phoratoxins (A-F) are toxic to mammalian cells. Phoratoxins A and B are toxic to rats at a concentration of $0.5-1 \mu \mathrm{g} / \mathrm{kg}$. Phoratoxins $\mathrm{C}-\mathrm{F}$ inhibit growth of different solid tumor cells, while phoratoxin $\mathrm{C}$ selectively inhibits growth of breast cancer cells (Johansson et al., 2003). The thionin Thi2.1 from A thaliana has anticancer activity as well; it kills $94 \%$ of MCF-7 and $38 \%$ of HeLa cells. Moreover, this thionin is cytotoxic to bovine endothelial and mammary epithelial cells (Loeza-Ángeles et. al., 2008). The results obtained indicate that cytotoxity of thionins is not selective; however, these peptides are promising candidates for the development of novel anticancer drugs.

Toxicity of thionins to different types of cells points to their defensive role against pathogens in vivo. This role is also supported by other data, such as synthesis of thionins in response to pathogen attack (Bohlmann et al., 1998), localization of thionins in "vulnerable" tissues (Orru et al., 1997), enhanced resistance of transgenic plants expressing thionin genes (see below), and decreased resistance to pathogens of thionin-silenced plants (Rayapuram et al., 2008). For example, in barley invaded by aphids Rhopalosiphum padi, Myzus persicae and Myzus cerasi, up-regulation of several thionin genes was revealed by transcriptome analysis, especially in barley plants infected with $M$. persicae and to a lesser extent, after $R$. padi invasion. The ectopic expression of two of these genes in Nicotiana benthamiana decreased sensitivity to M. persi$c a e$, suggesting that thionins do play a role in defense against aphids (Escudero-Martinez et al., 2017). On the other hand, silencing of thionin genes results in decreased resistance. In thionin-silenced Nicotiana attenuata plants, more plants were infected with opportunistic Pseudomonas species as compared 
to wild-type plants and more of them died from infection (Rayapuram et al., 2008).

In the development of novel antimicrobial agents, high toxicity of thionins to various pathogens and insect and mammalian cells forms the basis for their practical application in design of biologically active analogues with more simple structure (Vila-Perelló et al., 2006).

Although the main function of thionins is protection against pathogens, they also serve as storage proteins and participate in such processes as maturation and germination of seeds, packaging of storage proteins into protein bodies and their mobilization during germination.

\section{Mode of action}

Toxicity of thionins is considered to be associated with membrane permeabilization (Carrasco et al., 1981) which is inhibited by mono- and bivalent metal ions (Oard et al., 2007). Using barley $\alpha$-hordothionin as an example, a mechanism of thionin-mediated membrane permeabilization based on molecular modeling was suggested. According to this model, thionin forms a water-selective channel in the membrane, leading to water leakage into the lipid bilayer and local membrane disruption (Oard, 2011). Thionin-triggered changes in membrane permeability lead to a number of other processes, such as membrane depolarization, increased permeability for $\mathrm{Ca}^{2+}$ and $\mathrm{K}^{+}$ions, and activation of a number of enzymes (Stec, 2006). All these secondary processes can enhance the primary toxic effect of thionins and lead to complete destruction of cells. Obviously, membrane permeabilization by thionins is based on some universal process and is not mediated by interactions with specific receptors at the surface of target cells. According to P. Hughes and colleagues (2000), thionin toxicity is due to formation of ion channels in cell membranes by direct interaction with the surface of lipids. However, J.A. Richard with colleagues (2002) supposes that thionins partially incorporate into the lipid membrane due to electrostatic interactions that makes membranes more rigid and enhances fluidity at the edges of interphase regions. Electrostatic interaction of thionins with particular groups of phospholipid molecules contributes to the formation of negatively charged patches consisting of phospholipids. These patches formed by toxins increase the fluidity of membranes and withdraw phospholipids, thus intensifying instability of membranes and turning their lysis irreversible (Stec et al., 2004).

Along with membrane permeabilization, thionins affect intracellular targets: they activate endogenous phospholipase $\mathrm{A}_{2}$ (Vernon, Bell, 1992) and adenylate cyclase (Huang et al., 1994). $\beta$-purothionin inhibits protein kinase $C$ and binds calmodulin. Purothionins inhibit ribinucleotide reductase and $\beta$-glucoronidase (Diaz et al., 1992). Viscotoxins are suggested to interact directly with DNA or RNA that leads to inhibition of synthesis of nucleic acids and proteins (Woynarowski, Konopa, 1980; Li et al., 2002). Moreover, they were shown to possess immunomodulatory activity (Tabiasco et al., 2002). All the revealed toxic activities of thionins begin with membrane disruption and disturb key cellular processes that may finally result in cell death. The accumulating data indicate that thionins act not only on intracellular targets, but on secreted proteins of pathogens as well. For example, the study of the mode of action of the antifungal thionin Thi2.4 from $A$. thaliana showed that it binds to the secreted lectin of Fusarium graminearum, which induces death of leaf cells, thus protecting the plant from the toxic effect of the lectin (Asano et al., 2013).

\section{The use of thionin genes \\ for the improvement of disease resistance in plants}

Thionin genes have been successfully used for plant transformation and production of transgenic plants with enhanced resistance to both bacterial and fungal pathogens. In most cases, thionin genes of cereals served as transgenes. Let us consider some examples.

The gene of wheat $\beta$-purothionin under endogenous carbonic anhydrase promoter was introduced into the genome of A. thaliana (Oard, Enright, 2006). Even though high-level expression of $\beta$-purothionin gene was not observed, the transgenic plants demonstrated enhanced resistance to bacterial and fungal pathogens (Pseudomonas syringae strain DC3000 and F. oxysporum). $\beta$-purothionin expression in transgenic plants caused morphological abnormalities in fungal hyphae, while the extract from leaves of transgenic plant leaves increased membrane permeabilization in $R$. solani.

Expression of the barley $\alpha$-thionin gene in tobacco plants under $35 \mathrm{~S}$ promoter of cauliflower mosaic virus increased their resistance to two bacterial pathogens $-P$. syringae pv. tabaci and $P$. syringae pv. syringae (Carmona et al., 1993).

Black rot of sweet potato is caused by the fungus Ceratocystis fimbriata. The disease poses a serious problem for tropical and subtropical regions where sweet potato is cultivated, especially for such countries as India, China and Indonesia. The pathogenic fungus hinders growth and has a detrimental effect on the storage of roots. Transgenic sweet potato plants with incorporated gene of barley $\alpha$-hordothionin displayed high-level expression of $\alpha$-hordothionin mRNA in leaves and storage roots. Compared to non-transgenic plants, the transgenic plants showed reduced yellowing of leaves and smaller lesion areas around the sites inoculated with $C$. fimbriata spores. The obtained results demonstrate the vast potential of thionin genes for improving resistance of sweet potato to black rot (Muramoto et al., 2012).

The rice thionin gene OsTH17 was used to produce transgenic rice lines cv. Nipponbare (Ji et al., 2015). The transgenic rice plants were less susceptible to the oomycete Pythium graminicola and the nematode Meloidogyne graminicola, which are two most damaging root pathogens of rice. Two main bacterial pathogens infecting rice, namely Burkholderia plantarii и Burkholderia glumae, are also a serious problem for rice cultivation. Endogenous thionin genes are expressed constitutively in the coleoptiles, which is the target organ for the bacteria. However, expression of endogenous thionin genes is not enough for resistance to these pathogens. To cope with this problem, transgenic rice plants with an oat thionin gene were generated, and high-level accumulation of the thionin in cell walls was observed. Germination of seeds from nontransgenic plants in the presence of the bacteria resulted in early yellowing and death of seedlings. On the contrary, transgenic seedlings, in which the oat thionin gene was expressed, grew normally. Thus, this thionin efficiently protected rice plants against bacterial infection (Iwai et al., 2002). 
For transformation of apple-trees, the gene encoding barley $\alpha$-hordothionin was used (Krens et al., 2011). In the field, four of six transgenic lines appeared to be much more resistant to the fungal pathogen Venturia inaequalis causing scrab. The resistance persisted over four years of observation, and the hordothionin gene expression level was also constant.

The Arabidopsis thionin gene Thi2.1 under a fruit-inactive promoter was used to produce transgenic tomato plants with enhanced resistance to bacterial and Fusarium wilt. Constitutive expression of the transgene was observed in roots and leaves of tomato plants. Transgenic plants turned to be less susceptible than wild-type plants to both bacterial and Fusarium wilt. In transgenic lines, suppression of bacterial pathogen replication was recorded (Chan et al., 2005). The same thionin gene of Arabidopsis was used to enhance resistance of the susceptible ecotype Columbia (Col-2) to F. oxysporum f. sp. matthiolae infection. Increased resistance was confirmed by suppression of the fungal growth on transgenic plants. Moreover, growth abnormalities in hyphae, such as hyperbranching, were noted (Epple et al., 1997).

In conclusion, it should be noted that although thionins have been known for a long time, their high toxicity to a wide range of bacteria and fungi pathogenic to plants and humans, insects and cancer cells makes these peptides highly promising for the development of novel pharmaceuticals and plant disease control agents. Further detailed studies of the mode of action of thionins will enable creation of novel molecules with improved properties for practical application in agriculture and medicine.

\section{Acknowledgements}

This study was supported by Russian Science Foundation (grant No. 16-16-00032).

\section{Conflict of interest}

The authors declare no conflict of interest.

\section{References}

Asano T., Miwa A., Maeda K., Kimura M., Nishiuchi T. The secreted antifungal protein thionin 2.4 in Arabidopsis thaliana suppresses the toxicity of a fungal fruit body lectin from Fusarium graminearum. PLoS Pathog. 2013;9(8):e1003581. DOI 10.1371/journal. ppat. 1003581 .

Balls A.K., Hale W.S., Harris T.H. A crystalline protein from a lipoprotein of wheat flour. Cereal Chem. 1942;19:279-288.

Berrocal-Lobo M., Molina A., Rodriguez-Palenzuela P., Garcia-Olmedo F., Rivas L. Leishmania donovani: thionins, plant antimicrobial peptides with leishmanicidal activity. Exp. Parasitol. 2009;122: 247-249.

Bohlmann H. The role of thionins in plant protection. Crit. Rev. Plant Sci. 1994;13:1-16.

Bohlmann H., Vignutelli A., Hilpert B., Miersch O., Wasternack C., Apel K. Wounding and chemicals induce expression of the Arabidopsis thaliana gene Thi2.1, encoding a fungal defense thionin, via the octadecanoid pathway. FEBS Lett. 1998;437(3):281-286.

Carmona M.J., Molina A., Fernandez J.A., Lopez-Fando J.J., GarciaOlmedo F. Expression of the $\alpha$-thionin gene from barley in tobacco confers enhanced resistance to bacterial pathogens. Plant J. 1993; 3(3):457-462.

Carrasco I., Vazquez D., Hernandez-Lucas C., Carbonero P., GarciaOlmedo F. Thionins: plant peptides that modify membrane permeability in cultured mammalian cells. Eur. J. Biochem. 1981;116(1): 185-189.
Castagnaro A., Maraña C., Carbonero P., García-Olmedo F. Extreme divergence of a novel wheat thionin generated by a mutational burst specifically affecting the mature protein domain of the precursor. J. Mol. Biol. 1992;224(4):1003-1009.

Chan Y.L., Prasad V., Sanjaya, Chen K.H., Liu P.C., Chan M.T., Cheng C.P. Transgenic tomato plants expressing an Arabidopsis thionin (Thi2.1) driven by fruit-inactive promoter battle against phytopathogenic attack. Planta. 2005;221(3):386-393. DOI 10.1007/ s00425-004-1459-3.

Coulon A., Berkane E., Sautereau A.M., Urech K., Rouge P., Lopez A. Modes of membrane interaction of a natural cysteine-rich peptide: viscotoxin A3. Biochim. Biophys. Acta. 2002;1559(2):145-159. DOI 10.1016/S0005-2736(01)00446-1.

Coulson E.J., Harris T.H., Axelrod B. Effect on small laboratory animals of the injection of the crystalline hydrochloride of a sulfur protein from wheat flour. Cereal Chem. 1942;19:301-307.

de Souza Cândido E., e Silva Cardoso M.H., Sousa D.A., Viana J.C., de Oliveira-Júnior N.G., Miranda V., Franco O.L. The use of versatile plant antimicrobial peptides in agribusiness and human health Peptides. 2014;55:65-78. DOI 10.1016/j.peptides.2014.02.003.

Diaz I., Carmona M.J., Garcia-Olmedo F. Effects of thionins on betaglucuronidase in vitro and in plant protoplasts. FEBS Lett. 1992; 296(3):279-282. DOI 10.1016/0014-5793(92)80304-Y.

Egorov T.A., Odintsova T.I. Defense peptides of plant immune system. Russ. J. Bioorg. Khim. 2012;38(1):1-9. DOI 10.1134/ S1068162012010062.

Epple P., Apel K., Bohlmann H. Overexpression of an endogenous thionin enhances resistance of Arabidopsis against Fusarium oxysporum. Plant Cell. 1997;9(4):509-520. DOI 10.1105/tpc.9.4.509.

Escudero-Martinez C.M., Morris J.A., Hedley P.E., Bos J.I.B. Barley transcriptome analyses upon interaction with different aphid species identify thionins contributing to resistance. Plant Cell Environ. 2017;40(11):2628-2643. DOI 10.1111/pce.12979.

Fernandez de Caleya R., Gonzalez-Pascual B., Garcia-Olmedo F., Carbonero P. Susceptibility of phytopathogenic bacteria to wheat purothionins in vitro. Appl. Microbiol. 1972;23(5):998-1000.

Guzmán-Rodríguez J.J., Ochoa-Zarzosa A., López-Gómez R., LópezMeza J.E. Plant antimicrobial peptides as potential anticancer agents. Biomed. Res. Int. 2015;2015:735087. DOI 10.1155/2015/735087.

Huang W., Vernon L.P., Bell J.D. Enhancement of adenylate cyclase activity in S49 lymphoma cell membranes by the toxin thionin from Pyrularia pubera. Toxicon. 1994;32(7):789-797.

Hughes P., Dennis E., Whitecross M., Llewellyn D., Gage P. The cytotoxic plant protein, $\beta$-purothionin, forms ion channels in lipid membranes. J. Biol. Chem. 2000;275(2):823-827. DOI 10.1074/jbc. 275.2.823.

Iwai T., Kaku H., Honkura R., Nakamura S., Ochiai H., Sasaki T., Ohashi Y. Enhanced resistance to seed-transmitted bacterial diseases in transgenic rice plants overproducing an oat cell-wall-bound thionin. Mol. Plant Microbe Interact. 2002;15(6):515-521. DOI 10.1094/ MPMI.2002.15.6.515.

Ji H., Gheysen G., Ullah C., Verbeek R., Shang C., De Vleesschauwer D., Höfte M., Kyndt T. The role of thionins in rice defence against root pathogens. Mol. Plant Pathol. 2015;16(8):870-881. DOI $10.1111 / \mathrm{mpp} .12246$

Johansson S., Gullbo J., Lindholm P., Ek B., Thunberg E., Samuelsson G., Larsson R., Bohlin L., Claeson P. Small, novel proteins from the mistletoe Phoradendron tomentosum exhibit highly selective cytotoxicity to human breast cancer cells. Cell. Mol. Life Sci. 2003; 60(1):165-175. DOI 10.1007/s000180300011.

Kong J.L., Du X.B., Fan C.X., Xu J.F., Zheng X.J. Determination of primary structure of a novel peptide from mistletoe and its antitumor activity. Acta Pharmaceutica Sinica. 2004;39(10):813-817.

Kramer K.J., Klassen L.W., Jones B.L., Speirs R.D., Kammer A.E. Toxicity of purothionin and its homologues to the tobacco hornworm, Manduca sexta (L.) (Lepidoptera: Sphingidae). Toxicol. Appl. Pharmacol. 1979;48:179-183. 
Krens F.A., Schaart J.G., Groenwold R., Walraven A.E.J., Hesselink T., Thissen J.T.N.M. Performance and long-term stability of the barley hordothionin gene in multiple transgenic apple lines. Transgenic Res. 2011;20:1113-1123. DOI 10.1007/s11248-011-9484-z.

Li S.-S., Gullbo J., Lindholm P., Larsson R., Thunberg E., Samuelsson G., Bohlin L., Claeson P. Ligatoxin B, a new cytotoxic protein with a novel helix-turn-helix DNA-binding domain from the mistletoe Phoradendron liga. Biochem. J. 2002;366(2):405-413. DOI 10.1042/bj20020221.

Loeza-Ángeles H., Sagrero-Cisneros E., Lara-Zárate L., VillagómezGómez E., López-Meza J.E., Ochoa-Zarzosa A. Thionin Thi2.1 from Arabidopsis thaliana expressed in endothelial cells shows antibacterial, antifungal and cytotoxic activity. Biotechnol. Lett. 2008; 30(10):1713-1719. DOI 10.1007/s10529-008-9756-8.

Molina A., Goy P.A., Fraile A., Sanchez-Monge R., Garcia-Olmedo F. Inhibition of bacterial and fungal plant pathogens by thionins of types I and II. Plant Sci. 1993;92:169-177.

Muramoto N., Tanaka T., Shimamura T., Mitsukawa N., Hori E., Koda K., Otani M., Hirai M., Nakamura K., Imaeda T. Transgenic sweet potato expressing thionin from barley gives resistance to black rot disease caused by Ceratocystis fimbriata in leaves and storage roots. Plant Cell Rep. 2012;31(6):987-997. DOI 10.1007/s00299011-1217-5.

Oard S.V. Deciphering a mechanism of membrane permeabilization by $\alpha$-hordothionin peptide. Biochim. Biophys. Acta. 2011;1808(6): 1737-1745. DOI 10.1016/j.bbamem.2011.02.003.

Oard S.V., Enright F.M. Expression of the antimicrobial peptides in plants to control phytopathogenic bacteria and fungi. Plant Cell Rep. 2006;25(6):561-572. DOI 10.1007/s00299-005-0102-5.

Oard S., Karki B., Enright F. Is there a difference in metal ion-based inhibition between members of thionin family: molecular dynamics simulation study. Biophys. Chem. 2007;130(1-2):65-75. DOI 10.1016/j.bpc.2007.07.005.

Oard S., Rush M.C., Oard J.H. Characterization of antimicrobial peptides against a US strain of the rice pathogen Rhizoctonia solani. J. Appl. Microbiol. 2004;97(1):169-180. DOI 10.1111/j.1365-2672. 2004.02291.x

Ochoa-Zarzosa A., Loeza-Angeles H., Sagrero-Cisneros E., Villagómez-Gómez E., Lara-Zárate L., López-Meza J.E. Antibacterial activity of thionin Thi2.1 from Arabidopsis thaliana expressed by bovine endothelial cells against Staphylococcus aureus isolates from bovine mastitis. Vet. Microbiol. 2008a;127(3-4):425-430. DOI 10.1016/j.vetmic.2007.08.031.

Ochoa-Zarzosa A., Loeza-Lara P.D., Torres-Rodríguez F., Loeza-Angeles H., Mascot-Chiquito N., Sánchez-Baca S., López-Meza J.E. Antimicrobial susceptibility and invasive ability of Staphylococcus aureus isolates from mastitis from dairy backyard systems. Antonie Van Leeuwenhoek. 2008b;94(2):199-206. DOI 10.1007/s10482008-9230-6.

Orru S., Scaloni A., Giannattasio M., Urech K., Pucci P., Schaller G. Amino acid sequence, S-S bridge arrangement and distribution in plant tissues of thionins from Viscum album. Biol. Chem. 1997; 378(9):989-996.

Osório e Castro V.R., Vernon L.P. Stimulation of prothrombinase activity by the nonapeptide Thr-Trp-Ala-Arg-Asn-Ser-Tyr-Asn-Val, a segment of a plant thionin. Peptides. 2003;24(4):515-521. DOI 10.1016/S0196-9781(03)00115-3.

Plattner S., Gruber C., Stadlmann J., Widmann S., Gruber C.W., Altmann F., Bohlmann H. Isolation and characterization of a thionin proprotein-processing enzyme from barley. J. Biol. Chem. 2015; 290(29):18056-18067. DOI 10.1074/jbc.M115.647859.

Rao U., Teeter M.M. Improvement of turn structure prediction by molecular dynamics: a case study of alpha 1-purothionin. Protein Eng. 1993;6(8):837-847.

Rayapuram C., Wu J., Haas C., Baldwin I.T. PR-13/Thionin but not PR-1 mediates bacterial resistance in Nicotiana attenuata in nature, and neither influences herbivore resistance. Mol. Plant Microbe Interact. 2008;21(7):988-1000. DOI 10.1094/MPMI-21-7-0988.
Richard J.A., Kelly I., Marion D., Pezolet M., Auger M. Interaction between $\beta$-purothionin and dimyristoylphosphatidylglycerol: a ${ }^{31} \mathrm{P}-\mathrm{NMR}$ and infrared spectroscopic study. Biophys. J. 2002;83: 2074-2083. DOI 10.1016/S0006-3495(02)73968-4.

Romero A., Alamillo J.M., Garcia-Olmedo F. Processing of thionin precursors in barley leaves by a vacuolar proteinase. Eur. J. Biochem. 1997;243(1-2):202-208. DOI 10.1111/j.14321033.1997.0202a.x.

Sánchez-Monge R., Delibes A., Hernandéz-Lucas C., Carbonero P., García-Olmedo F. Homoeologous chromosomal location of the genes encoding thionins in wheat and rye. Theor. Appl. Genet. 1979; 54(2):61-63. DOI 10.1007/BF00265470.

Sarethy I.P. Plant peptides: bioactivity, opportunities and challenges. Protein Pept. Lett. 2017;24(2):102-108. DOI 10.2174/0929866523 666161220113632.

Schrader-Fischer G., Apel K. cDNA-derived identification of novel thionin precursors in Viscum album that contain highly divergent thionin domains but conserved signal and acidic polypeptide domains. Plant Mol. Biol. 1993;23(6):1233-1242.

Silverstein K.A., Moskal W.A., Jr., Wu H.C., Underwood B.A., Graham M.A., Town C.D., VandenBosch K.A. Small cysteine-rich peptides resembling antimicrobial peptides have been under-predicted in plants. Plant J. 2007;51(2):262-280. DOI 10.1111/j.1365313X.2007.03136.x.

Slavokhotova A.A., Shelenkov A.A., Odintsova T.I. Prediction of Leymus arenarius (L.) antimicrobial peptides based on de novo transcriptome assembly. Plant. Mol. Biol. 2015;89(3):203-214. DOI 10.1007/s11103-015-0346-6.

Stec B. Plant thionins - the structural perspective. Cell. Mol. Life Sci. 2006;63(12):1370-1385. DOI 10.1007/s00018-005-5574-5.

Stec B., Markman O., Rao U., Heffron G., Henderson S., Vernon L.P., Brumfeld V., Teeter M.M. Proposal for molecular mechanism of thionins deduced from physico-chemical studies of plant toxins. J. Pept. Res. 2004;64(6):210-224. DOI 10.1111/j.1399-3011.2004. 00187.x.

Stotz H.U., Waller F., Wang K. Innate immunity in plants: The role of antimicrobial peptides. Antimicrobial Peptides and Innate Immunity. Eds. S. Hiemstra, S.A.J. Zaat. Springer, 2013;29-51.

Stuart L.S., Harris T.H. Bactericidal and fungicidal properties of a crystalline protein from unbleached wheat flour. Cereal Chem. 1942;19: 288-300.

Tabiasco J., Pont F., Fournie J.J., Vercellone A. Mistletoe viscotoxins increase natural killer cell-mediated cytotoxicity. Eur. J. Biochem. 2002;269(10):2591-2600. DOI 10.1046/j.1432-1033.2002.02932.x.

Tam J.P., Wang S., Wong K.H., Tan W.L. Antimicrobial peptides from plants. Pharmaceuticals (Basel). 2015;8(4):711-757. DOI 10.3390/ ph8040711.

Taveira G.B., Carvalho A.O., Rodrigues R., Trindade F.G., Da Cunha M., Gomes V.M. Thionin-like peptide from Capsicum annuum fruits: mechanism of action and synergism with fluconazole against Candida species. BMC Microbiol. 2016;16:12. DOI 10.1186/ s12866-016-0626-6.

Taveira G.B., Mathias L.S., da Motta O.V., Machado O.L., Rodrigues R., Carvalho A.O., Teixeira-Ferreira A., Perales J., Vasconcelos I.M., Gomes V.M. Thionin-like peptides from Capsicum annuum fruits with high activity against human pathogenic bacteria and yeasts. Biopolymers. 2014;102(1):30-39. DOI 10.1002/ bip. 22351

Taveira G.B., Mello É.O., Carvalho A.O., Regente M., Pinedo M., de La Canal L., Rodrigues R., Gomes V.M. Antimicrobial activity and mechanism of action of a thionin-like peptide from Capsicum annuит fruits and combinatorial treatment with fluconazole against Fusarium solani. Biopolymers. 2017;108(3). DOI 10.1002/bip.23008.

Vernon L.P., Bell J.D. Membrane structure, toxins and phospholipase $\mathrm{A}_{2}$ activity. Pharmacol. Ther. 1992;54(3):269-295. DOI 10.1016/01637258(92)90003-I.

Vernon L.P., Evett G.E., Zeikus R.D., Gray W.R. A toxic thionin from Pyrularia pubera: purification, properties, and amino acid sequence. 
Arch. Biochem. Biophys. 1985;238(1):18-29. DOI 10.1016/00039861(85)90136-5.

Vila-Perelló M., Andreu D. Characterization and structural role of disulfide bonds in a highly knotted thionin from Pyrularia pubera. Biopolymers. 2005;80(5):697-707. DOI 10.1002/bip.20270.

Vila-Perelló M., Sánchez-Vallet A., García-Olmedo F., Molina A., Andreu D. Synthetic and structural studies on Pyrularia pubera thionin: a single-residue mutation enhances activity against Gram-negative bacteria. FEBS Lett. 2003;536(1-3):215-219. DOI 10.1016/S00145793(03)00053-X.

Vila-Perelló M., Sánchez-Vallet A., García-Olmedo F., Molina A., Andreu D. Structural dissection of a highly knotted peptide reveals mini- mal motif with antimicrobial activity. J. Biol. Chem. 2005;280(2): 1661-1668. DOI 10.1074/jbc.M410577200.

Vila-Perelló M., Tognon S., Sánchez-Vallet A., García-Olmedo F., Molina A., Andreu D. A minimalist design approach to antimicrobial agents based on a thionin template. J. Med. Chem. 2006;49(2):448451. DOI 10.1021/jm050882i.

Wada K., Ozaki Y., Matsubara H., Yoshizumi H. Studies on purothionin by chemical modifications. J. Biochem. 1982;91(1):257-263.

Woynarowski J.M., Konopa J. Interaction between DNA and viscotoxins. Cytotoxic basic polypeptides from Viscum album L. Hoppe Seylers Z. Physiol. Chem. 1980;361:1535-1545.

\section{ORCID ID}

T.I. Odintsova orcid.org/0000-0002-5563-9755

M.P. Slezina orcid.org/0000-0003-1653-5993

E.A. Istomina orcid.org/0000-0001-6426-6009 